\title{
Managing Zoonotic Tinea Corporis in Primary Care: A Case Report
}

\section{Zoonotik Tinea Corporis'in Birinci Basamakta Yönetimi: Bir Olgu Sunumu}

\author{
Gamze Akyol Misır ${ }^{* 1}$, Candan Kendir ${ }^{2}$, Azize Dilek Güldal ${ }^{3}$
}

\section{ABSTRACT}

Tinea corporis is a fungal infection caused by various dermatophytes. It is mostly seen on trunk and mostly represented with an annular plaque with erythematous border. Although it is presented with a typical lesion, even if the patient applies to primary care, it is mostly diagnosed and treated in secondary and tertiary care in Turkey. We present a 27-year-old woman that applied to primary care with an itchy, circular lesion. The woman was diagnosed with zoonotic tinea corporis due to Microsporum canis infection and treated in our Family Medicine Training Primary Healthcare Center successfully. This case is one of the few cases in the literature about the diagnosis and management of zoonotic tinea corporis in primary care. In order to decrease the workload and healthcare costs in secondary and tertiary care, management of these kinds of diseases in primary care should be encouraged.

Key words: Zoonoses, fungal skin diseases, general practice, family medicine

\section{ÖZET}

Tinea korporis, çeşitli dermatofitlerin neden olduğu bir mantar enfeksiyonudur. Sıklıkla gövdede, eritemli sinırları olan dairesel bir plak olarak kendini gösterir. Tipik bir lezyon ile kendini göstermesine rağmen, hasta birinci basamak sağlık kuruluşuna başvursa dahi, Türkiye'de sıklıkla ikinci ve üçüncü basamak sağlık kuruluşlarında tanı almakta ve tedavi edilmektedir. Burada birinci basamak sağlık kuruluşuna kaşıntılı ve yuvarlak bir lezyonla başvuran 27 yaşında bir kadın hastayı sunmaktayız. Hasta, Eğitim Aile Sağlığı Merkezi'mizde Microsporum canis enfeksiyonuna bağlı tinea korporis tanısı almış ve başarılı bir şekilde tedavi edilmiştir. Bu olgu, literatürde birinci basamakta zoonoz enfeksiyona bağlı tinea korporis'in tanısı ve tedavisi ile ilgili olarak yer alan sayılı olgu sunumlarından biridir. İkinci ve üçüncü basamak sağlık kuruluşlarının iş yükünü ve sağlık harcamalarını azaltabilmek için, aile hekimleri bu gibi hastalıkların birinci basamak sağlık kuruluşlarında yönetilmesi konusunda cesaretlendirilmelidir.

Anahtar kelimeler: Zoonozlar, fungal deri hastalıkları, aile hekimliği

Received Date / Geliş tarihi: 16.04.2018, Accepted Date / Kabul tarihi: 10.07.2018

${ }^{1}$ Yozgat No.10 Primary Healthcare Center, Yozgat, TURKEY

${ }^{2}$ École des Hautes Études en Santé Publique, Rennes, FRANCE

${ }^{3}$ Dokuz Eylül University, Faculty of Medicine, Department of Family Medicine, İzmir, TURKEY

*Address for Correspondence / Yazışma Adresi: Gamze Akyol Mısır, Yozgat No.10 Primary Healthcare Center, Yozgat, TURKEY

E-mail: gamze.akyolmisir@saglik.gov.tr

Misır Akyol G, Kendir C, Güldal AD. Managing Zoonotic Tinea Corporis in Primary Care: A Case Report. TJFMPC, 2019;13(1): 95-99.

DOI: $10.21763 /$ tjfmpc.528051 


\section{INTRODUCTION}

Tinea corporis (ringworm) is a common fungal infection caused by several dermatophytes such as Trichophyton spp, Microsporum spp and, Epidermophyton spp. It is mostly seen in children, yet could be seen in adults as geophilic, zoophilic or anthropic infections. The typical presentation of tinea corporis is sharply-circumscribed, slightly indurated plaque with erythematous edge. ${ }^{1,2}$

Microsporium canis (M. canis) is a common domestic animal infection which may be a cause of zoonotic infection in humans. ${ }^{2}$ In this report, we address a case of tinea corporis which occurred after contact with the domestic cat, infected with $M$. canis.

\section{CASE REPORT}

A 27-year-old, female patient who presented with itchy lesions on her back to our training primary health care center which is linked to Dokuz Eylul University's Department of Family Medicine. In her physical examination, two pruritic lesions measuring $3 \times 2 \mathrm{~cm}$ in diameter with a desquamated center and sharp erythematous and indurated borders were observed (Figure 1).

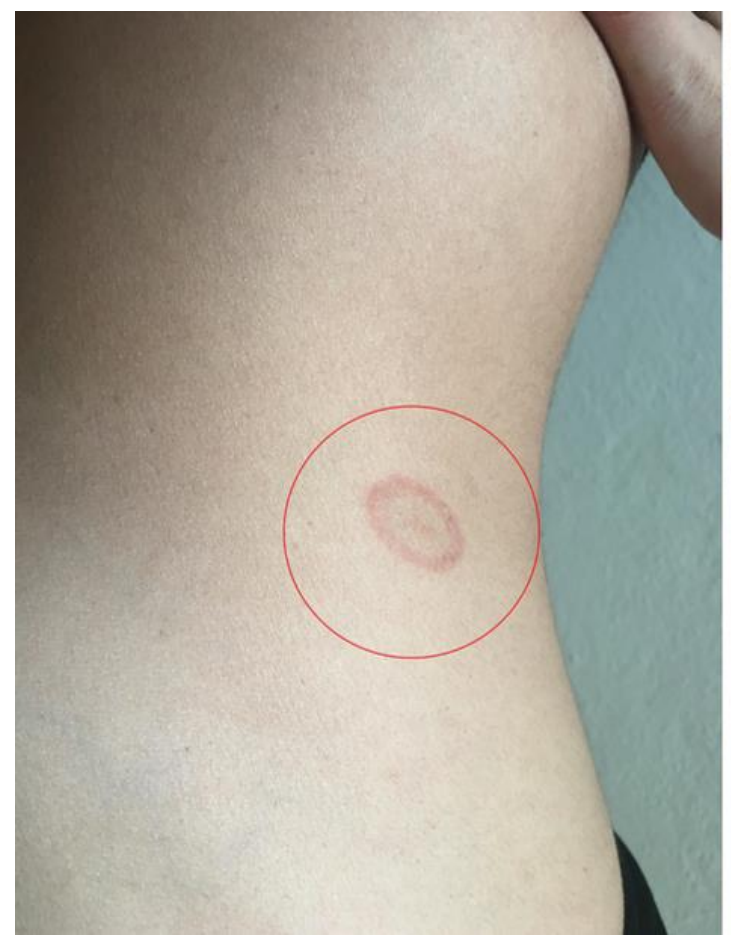

Figure 1: Patient's lesions before treatment

She didn't have any history of medication intake, immunosuppression, hospitalization or any diagnosis of chronic diseases before the appearance of the lesions. She stated that she lives with her spouse who had no recent sign of dermal infection. Within the concept of understanding the patient illness experience, she was questioned of her living status, effects of the symptoms on her daily life and her opinion about the disease itself and the reasons behind it as part of the patient-centered clinical approach in family medicine. She mentioned that she is concerned about her cat's problem

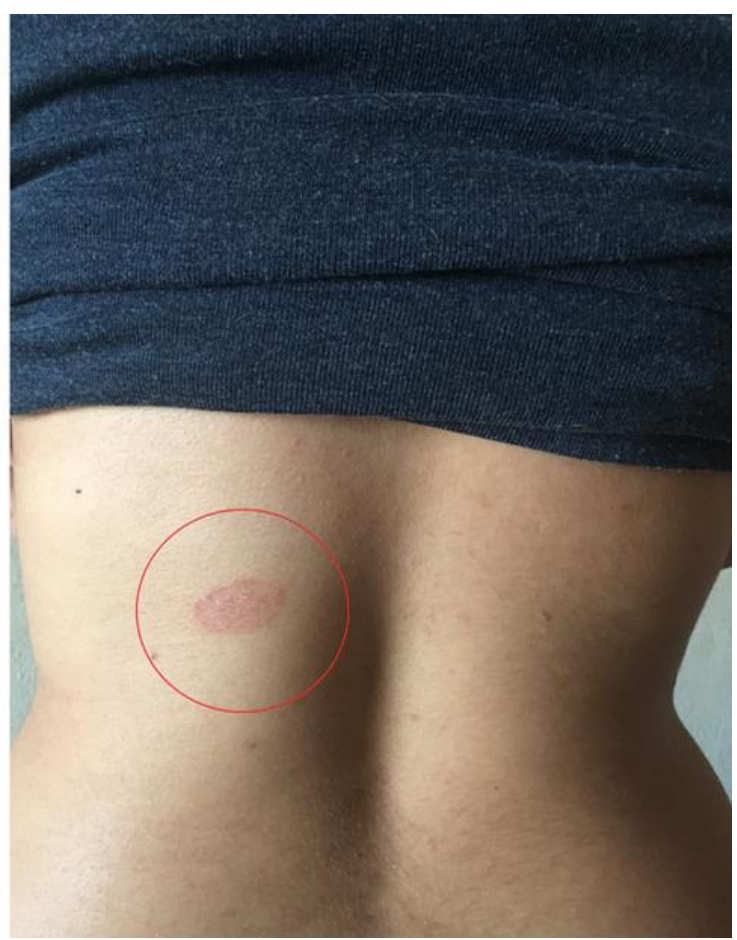

which could be the reason of her lesions. She had a domestic cat which never leaves the house and he was consulted to the veterinarian because of hair loss on his left ear two weeks ago (Figure 2). The veterinarian diagnosed the cat with a fungal infection and started a local treatment. With detailed assessment of the medical records of the veterinarian, it was noted that the source of infection was $M$. canis and the ingredient of the prescription was local miconazole nitrate $\quad-\quad$ chlorhexidine hydrochloride combination. 


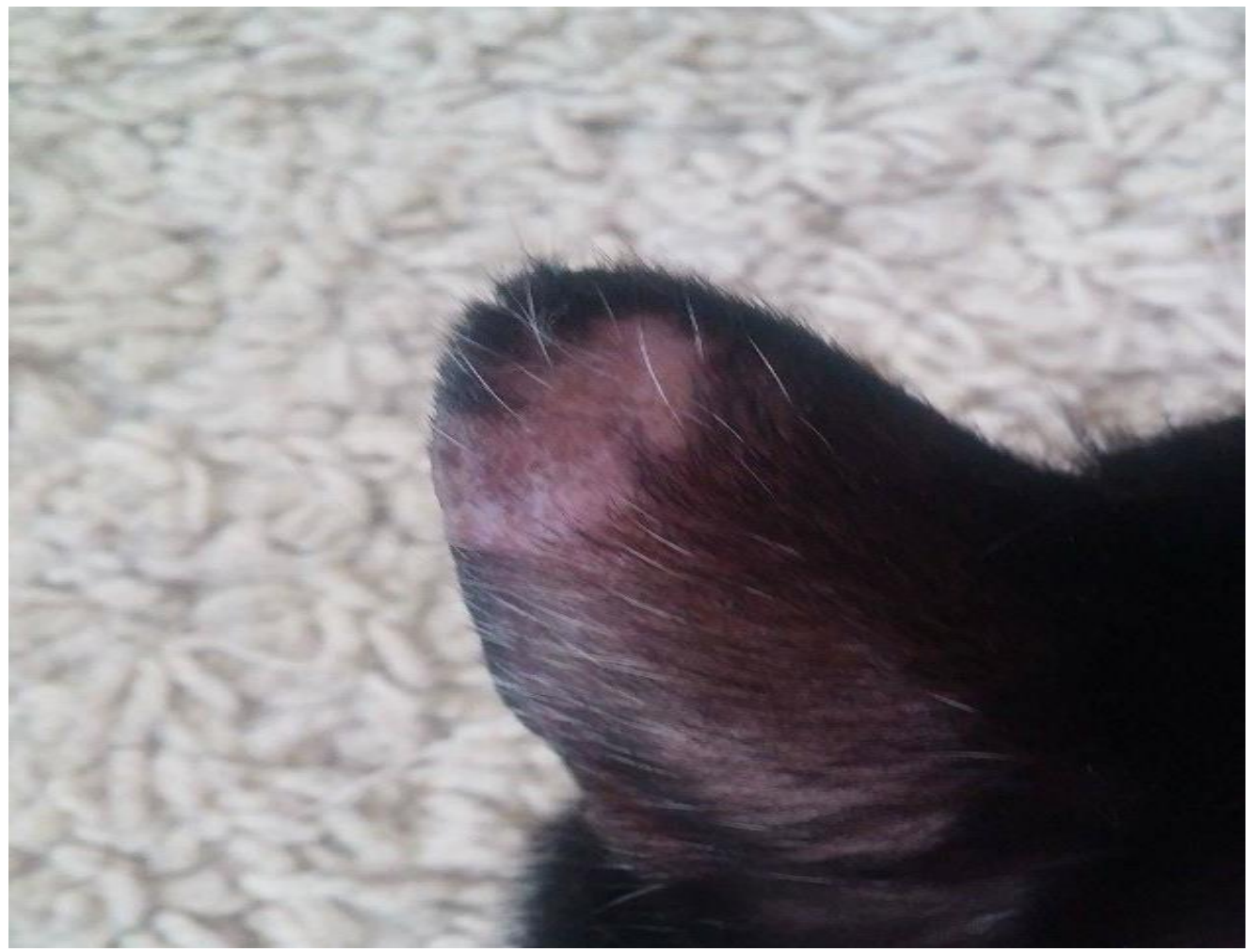

Figure 2: Fungal infection on patient's domestic cat's ear

All in all, our patient was pre-diagnosed with tinea corporis due to $M$. canis infection and local terbinafine twice a day was prescribed. In addition, she was consulted to a dermatologist with final diagnosis. Three weeks later, she applied to our clinic with regressed skin lesions (Figure 3). The dermatology consultation reports showed that $M$. canis was detected with $\mathrm{KOH}$ preparation and cultural examination of skin scrape samples. The dermatologist agreed on our treatment and recommended it for at least three weeks.

Informed written consent was taken from our patient.
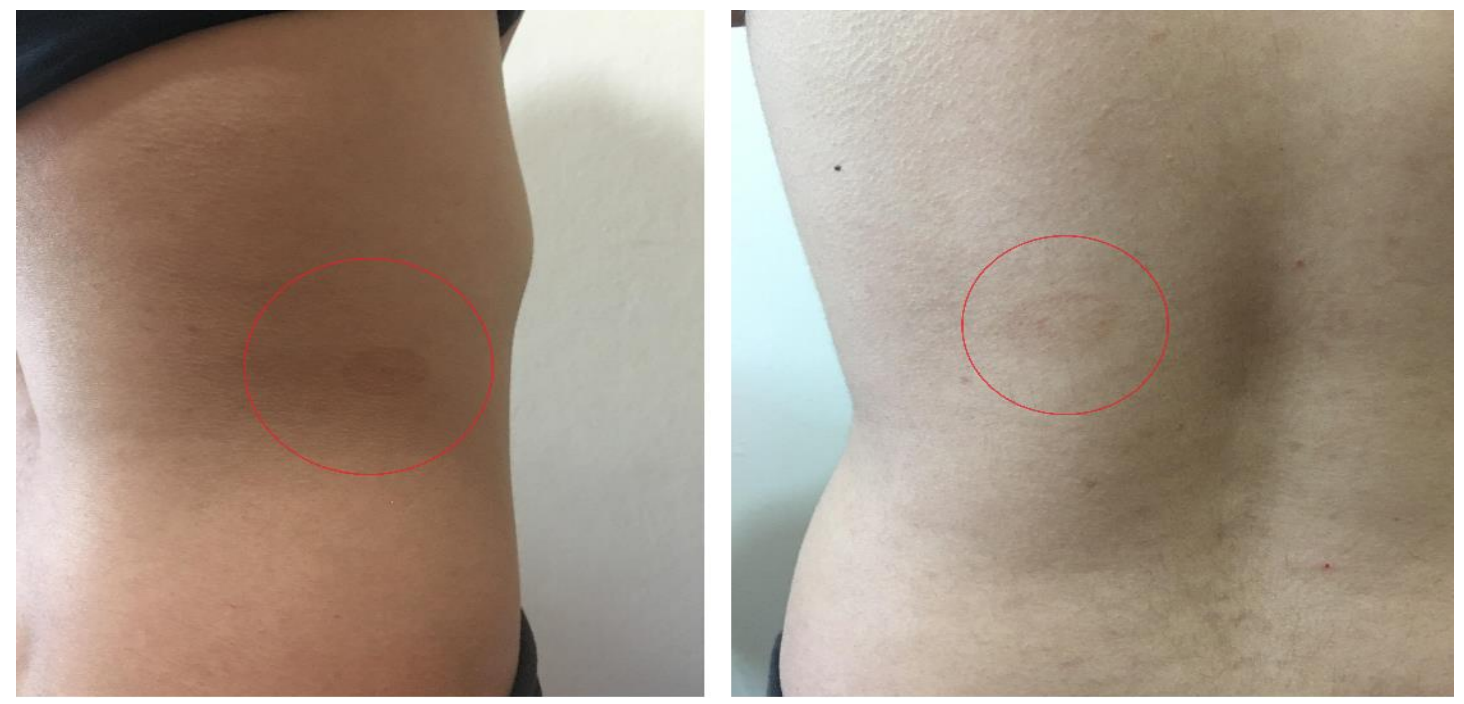

Figure 3: Patient's regressed lesions after treatment 


\section{DISCUSSION}

Tinea corporis is a common fungal infection which is usually located on body and extremities. The characteristic lesions are presented as sharp-edged plaques with the desquamated center and erythematous and indurated borders. ${ }^{1,2}$ Although it is mostly caused by Trichopyhton spp infections, it may be also caused by zoonotic Microsporum spp.

The disease could be diagnosed with clinical appearance of typical lesions. ${ }^{3}$ Still, characteristic lesions of tinea corporis might be misdiagnosed as nummular eczema, pityriasis versicolor, psoriasis, pityriasis rosea, subacute cutaneous lupus erythematosus and the treatment varies among each diagnosis. ${ }^{3}$ The detailed medical history taking could be directive for the identification of the agent. Additionally, direct microscopy of $\mathrm{KOH}$ preparation, the culture of the skin scrape sample in saboreud dextrose agar and/or PCR of DNA isolation could be performed when there is doubt in clinical diagnosis. ${ }^{2,3}$

Local and uncomplicated lesions of tinea corporis are usually responsive to topical treatment with terbinafine, twice daily for at least three weeks. In order to manage widespread or complicated infections or patients with immune deficiency or infections that are non-responsive to local treatment, oral antifungal agents may be indicated. ${ }^{3}$

In Turkey, there are special training programs for General Practice (GP)/Family Medicine (FM) in several universities and education and training hospitals. These trainees are educated in the principles of the family medicine discipline and trained in various medical departments including Dermatology and Venereology.

The patient-centered clinical approach is one of the core competencies of the GP/FM. It includes the ability to use a biopsychosocial model taking into account cultural and existential dimensions in addition to biomedical approach of other medical specialties. $^{4}$ Additionally, it increases the compliance of the patient to treatment, reduces the conflicts between the patient and the doctor and increases the patient's functionality during the recovery period. ${ }^{4}$

In our case, the patient was assessed within the concept of patient-centered clinical approach and holistic approach. The detailed medical history taking led us to the nearly direct diagnosis and management of M.canis infection.
In the literature, a few tinea corporis cases in adults due to zoonotic M.canis infection were reported. ${ }^{5-9}$ However, these cases were all evaluated in the secondary or tertiary health care centers. As FPs don't have a gatekeeper role in Turkey due to lack of referral system, a comprehensive approach and management in primary care could decrease the workload and patient overload in secondary or tertiary health care centers. Additionally, that could result in decrease of health care costs due to differences in costs of consultations in different healthcare centers. $^{4}$

\section{CONCLUSIONS}

This case was discussed due to lack of data about the diagnosis and management of tinea corporis related to M.canis infection in medical literature regarding primary care. As it is seen in our case, special education in GP/FM or continuing medical education could help FPs to handle similar cases in primary care. Moreover, development of specific guidelines for primary care in diagnosis and management of these kind of diseases will increase FPs' confidence to manage diseases that could be handled without further consultations.

\section{Conflict of interest:}

None declared.

\section{REFERENCES}

1. Gawkrodger D, Ardern-Jones MR. Dermatology: an illustrated colour text. Elsevier Health Sciences; 2016. p.30-31.

2. Gupta AK, Tu LQ. Dermatophytes: Diagnosis and treatment. J Am Acad Dermatol. 2006 Jun;54(6):1050-5.

3. Crawford F, Hollis S. Topical treatments for fungal infections of the skin and nails of the foot. Cochrane Database Syst Rev. 2007;3.

4. Europe W. The European definition of general practice/family medicine. Barc WONCA Eur. 2002.

5. Aytimur, Derya, S. E. Yuksel, and I. Ertam. "A case with tinea corporis et faciei due to Microsporum canis from a symptomatic cat." Ege Medicine J44 (2005): 67-9.

6. Gerçeker B, Ertam İ, Aytimur D. Olgu Sunumu: Kediden Bulaşan Bir Tinea Korporis Olgusu. Sürekli Tip Eğitimi Dergisi (STED) 13.10 (2004): 392-3.

7. Kokollari F, Daka A, Blyta Y, Ismajli F, Haxhijaha-Lulaj K. Tinea Corporis, Caused by Microsporum Canis - a Case 
Report From Kosovo. Med Arch. 2015 Oct;69(5):345-6.

8. Mancianti F, Nardoni S, Corazza M, D'achille P, Ponticelli C. Environmental detection of Microsporum canis arthrospores in the households of infected cats and dogs. J Feline Med Surg. 2003;5(6):323-8.

9. Nardoni, Simona, et al. "Open-field study comparing an essential oil-based shampoo with miconazole/chlorhexidine for haircoat disinfection in cats with spontaneous microsporiasis." J Feline Med Surg. 19.6 (2017): 697-701. 